\title{
顎矯正手術におけるポリ-L-乳酸／ポリ-D-乳酸／ポリグリコール酸 生体吸収性骨接合材の臨床評価
}

\author{
小 林 正 治 ${ }^{1)}$ 齊 藤 力 ${ }^{1)}$ 小 村 健 ${ }^{2)}$ \\ 原田 清 ${ }^{3)}$ 橋 本 賢 二 ${ }^{4}$ 加 納 浩 之 ${ }^{1)}$ \\ 高 田 佳 之 ${ }^{1)}$
}

\section{Clinical Evaluation of Resorbable Poly (L-Lactide/D-Lactide/Glycolide) Bone Fixation Devices in Orthognathic Surgery}

\author{
Tadaharu KOBAYASHI ${ }^{1}$, Chikara SAITO ${ }^{1)}$, Ken OMURA ${ }^{2)}$, \\ KIYoshi HARADA ${ }^{3)}$, KenJI HASHIMOTO ${ }^{4}$, HIROYUKI KANO ${ }^{1)}$ \\ and YoshIYUKI TAKATA ${ }^{1)}$
}

\begin{abstract}
The clinical efficacy and safety of new resorbable plate and screw fixation devices for maxillary stabilization in orthognathic surgery were evaluated in this study. The plate and screw fixation devices were fabricated from a unique tripolymer composed of poly L-Lactide/ D-Lactide/Glycolide with a molecular ratio of 85/5/10. From August 2002 to May 2003, we conducted a clinical trial, using the resorbable devices for fixation of the maxilla at osteotomy sites of thirty patients. In all patients, the fixation of bony fragments was evaluated at the time of the operation, and the postoperative course and complications were evaluated by clinical and CT findings and by blood and urine examinations for 6 months following surgery.

All patients had satisfactory results from surgery. While none of the patients had any evidence of adverse
\end{abstract}

tissue reactions such as facial swelling, erythema, and/or radiographic osteolysis at 6 months after surgery, mild tenderness remained at three implantation sites in two patients in the clinical evaluation. Blood and urine examination showed no evidence of a cause-and-effect relationship between abnormal examination values and fixation devices. In radiographic evaluations at 6 months after surgery, bone adhesions were obscure in sixteen patients, but the fixations were maintained in all cases. These results of clinical and radiographic evaluations provide evidence that osteosynthesis can be safely and effectively completed in fixation of the maxilla with the resorbable plate and screw fixation devices.

Key words: resorbable bone fixation devices (吸収 性骨接合材), composition of poly L-Lactide/D-Lactide/ Glycolide（ポリ-L-乳酸／ポリ-D-乳酸／ポリグリコール酸 共重合体), fixation of maxilla（上䕱骨骨接合）

[Received Jul. 15, 2011]

1) 新潟大学大学院医歯学総合研究科口腔生命科学専攻顎顔面再建学講座組織再建口腔外科学分野 (主任 : 齊藤 力教授)

2) 東京医科歯科大学大学院医歯学総合研究科口腔機能再構築学系口腔機能再建学講座顎口腔外科学分野 (主任 : 小村 健教授)

3) 山梨大学大学院医学工学総合研究部医学学域歯科口腔外科学講座 (主任 : 原田 清教授)

4) 浜松医科大学歯科口腔外科（主任：加藤文度准教授）

1) Division of Reconstructive Surgery for Oral and Maxillofacial Region, Department of Tissue Regeneration and Reconstruction, Course for Oral Life Science, Niigata University Graduate School of Medical and Dental Sciences (Chief: Prof. Chikara SAITO)

2) Section of Oral and Maxillofacial Surgery, Department of Oral Restitution, Division of Oral Health Sciences, Graduate School, Tokyo Medical and Dental University (Chief: Prof. Ken OMURA)

3) Department of Oral and Maxillofacial Surgery, Division of Medicine, Interdisciplinary Graduate School of Medicine and Engineering, University of Yamanashi (Chief: Prof. Kiyoshi HARADA)

4) Department of Oral and Maxillofacial Surgery, Hamamatsu University School of Medicine (Chief: Associate Prof. Fuminori KATO) 


\section{緒言}

現在, 顎顔面口腔外科手術における骨接合には生体親和 性に富んだチタンなどの金属材料から成るプレートシステ ムが広く用いられている。しかし, 金属製骨接合プレート システムでは金属元素の溶出や臓器への蓄積, 免疫系細胞 の反応 ${ }^{1-3)}$ が指摘されていることから, 多くの施設では術 後に除去術を施行している。近年, 除去の必要がない生体 内吸収性材料を用いた骨接合ミニプレートシステムの研究 が進み ${ }^{4,5)}$, 本邦でもポリ-L-乳酸製の製品が開発され臨床 に応用されている6-10)。

今回われわれは, ポリ-L-乳酸／ポリ-D-乳酸／ポリグリ コール酸の共重合体からなる新しい生体吸収性骨接合ミニ プレートシステム（NSK1403-DLT, Stryker, USA）の顎 矯正手術における臨床的有用性と安全性について検討し た。

\section{対象および方法}

本研究は, 厚生労働省の認可のもと第 III相試験（多施設 共同オープン試験）として行われた治験（治験実施計画書 番号：NSK1403-DLT, 治験総括医師：横浜市立大学医学 部形成外科教授 鳥飼勝行, 治験依頼者: 日本ストライ カー株式会社）の登録症例 83 例のうち顎矯正手術におけ る上顎骨接合症例 30 例（治験実施機関：新潟大学医歯学 総合病院口腔再建外科, 東京医科歯科大学歯学部附属病院 口腔外科, 浜松医科大学附属病院歯科口腔外科) を対象と して臨床的有用性と安全性について検討した。なお，本治 験はヘルシンキ宣言の精神を遵守し, かつ厚生労働省の 「医療用具の臨床試験の実施に関する基準」に従って実施 されており, 各医療機関の治験審査委員会の承認を得て, 治験担当医師が患者本人ならびに家族に対して同意説明 文, 補助資料等を用いて十分に説明し，その内容の理解が 得られた後, 自由意志による治験への参加の同意を文書で 得た上で実施した。

1. 生体吸収性骨接合ミニプレートシステム

今回使用した生体吸収性骨接合ミニプレートシステム (NSK1403-DLT, Stryker, USA）は, ポリ-L-乳酸／ポリ-D乳酸／ポリグリコール酸の共重合体（分子比：85/5/10） を加工したもので, 厚さ $1.0 \mathrm{~mm}$ のプレートと直径 $1.7 \mathrm{~mm}$, $2.2 \mathrm{~mm}, 2.6 \mathrm{~mm}$ のスクリューからなる。操作方法は, 以 下の通りである。(1)柔軟で容易に変形させることが可能な 亜鉛製テンプレートをプレート装着部骨面に合わせる。(2) 吸収性プレートは, 専用の加温器を用いて $60^{\circ} \mathrm{C} に$ 加温し た蒸留水中でこのテンプレートに沿わせることによって容 易に曲げることができる。(3)吸収性プレートを骨面に合わ せてドリリングを行い, タップを用いてねじ山を切る。(4) 直径 $1.7 \mathrm{~mm}$ もしくは $2.2 \mathrm{~mm}$ の吸収性スクリューで固定す
る (Fig. 1)。

\section{2. 対象症例}

対象は, 2002 年 8 月より 2003 年 5 月までに治験参加の 同意が得られ，顎矯正手術における上顎骨接合に本骨接合 材を使用した 30 名（男性 12 名, 女性 18 名）で, 手術時 平均年歯令は 24 歳 1 か月（16 歳 2 か月から 41 歳 7 か月） であった。手術の内訳は, 顎変形症患者に対する Le Fort I 型骨切り術と両側下顎枝矢状分割法施行症例が 27 例, Le Fort I 型骨切り術単独施行症例が 1 例, 上顎前歯部歯 槽骨切り術が 2 例であった。30 例とも梨状口側縁部の骨 接合に本骨接合材を使用した。Le Fort I 型骨切り術を施 行した 28 例中 3 例では両側梨状口側縁部と頓骨下稜下の 骨接合にも本骨接合材を使用した。また， 3 例では片側の 梨状口側縁部の骨接合にのみ本骨接合材を使用し, 25 例 では上顎骨接合にチタン製骨接合材を併用した。使用した 吸収性プレートは，L型が 38 枚，ストレートが 8 枚， C 型が 10 枚, ダブル Y 型が 4 枚, $\mathrm{Y}$ 型とボックス型がそれ ぞれ 1 枚, 合計 62 枚であった。吸収性スクリューは, 直径 $2.2 \mathrm{~mm}$ 長さ $6 \mathrm{~mm}$ が 197 本, 長さ $8 \mathrm{~mm}$ が 14 本, 直径 $1.7 \mathrm{~mm}$ 長さ $6 \mathrm{~mm}$ が 14 本, 長さ $4 \mathrm{~mm}$ が 66 本, 直径 $2.6 \mathrm{~mm}$ 長さ $6 \mathrm{~mm}$ が 3 本, 長さ $8 \mathrm{~mm}$ が 4 本, 合計 298 本であった。

3. 評価基準

1) 画像評価

骨癒合状態については, 術後 6 か月時に撮影した CT の 三次元画像ならびに多断面再構成画像所見から視認で “0（完全に骨癒合している）”，“1（骨癒合は不明瞭である がほぼ癒合して安定性が得られている)”, “2（骨癒合が不 明瞭でほとんど癒合しておらず安定性が得られていな い)”, “3（完全に骨癒合していない）”の 4 段階に評価し た (Table 1)。

\section{2) 臨床評価}

術後 1 か月, 3 か月ならびに 6 か月時に, 臨床評価とし て骨接合部の圧痛を“なし（痛みが感じられない）”, “軽 度（わずかな痛みが認められる）”, “中等度（明らかな痛 みが認められる)”, “重度（痛くて耐えられない）”４段 階に患者自身が評価した（Table 2)。固定の状況は“極め て良好 (接合した骨に動摇性は認められない)”, “良好 (接 合した骨に若干の動摇性が認められるが, 固定は十分に維 持されている)”, “やや不良（接合した骨に動摇性が認め られ, 固定力は多少維持されている)”, “不良（接合した 骨に動摇性が認められ, 固定されていない)”の 4 段階に 主治医が評価した（Table 3)。炎症反応は, “なし（紅斑 や浮腫が認められない)”, “軽度（わずかな紅斑が認めら れる)”, “中等度 (明らかな紅斑が認められる)”, “重度 (紅斑や浮腫が認められる)”の4段階に主治医が評価した (Table 4)。さらに本骨接合材の露出の有無を評価した (Table 5)。 


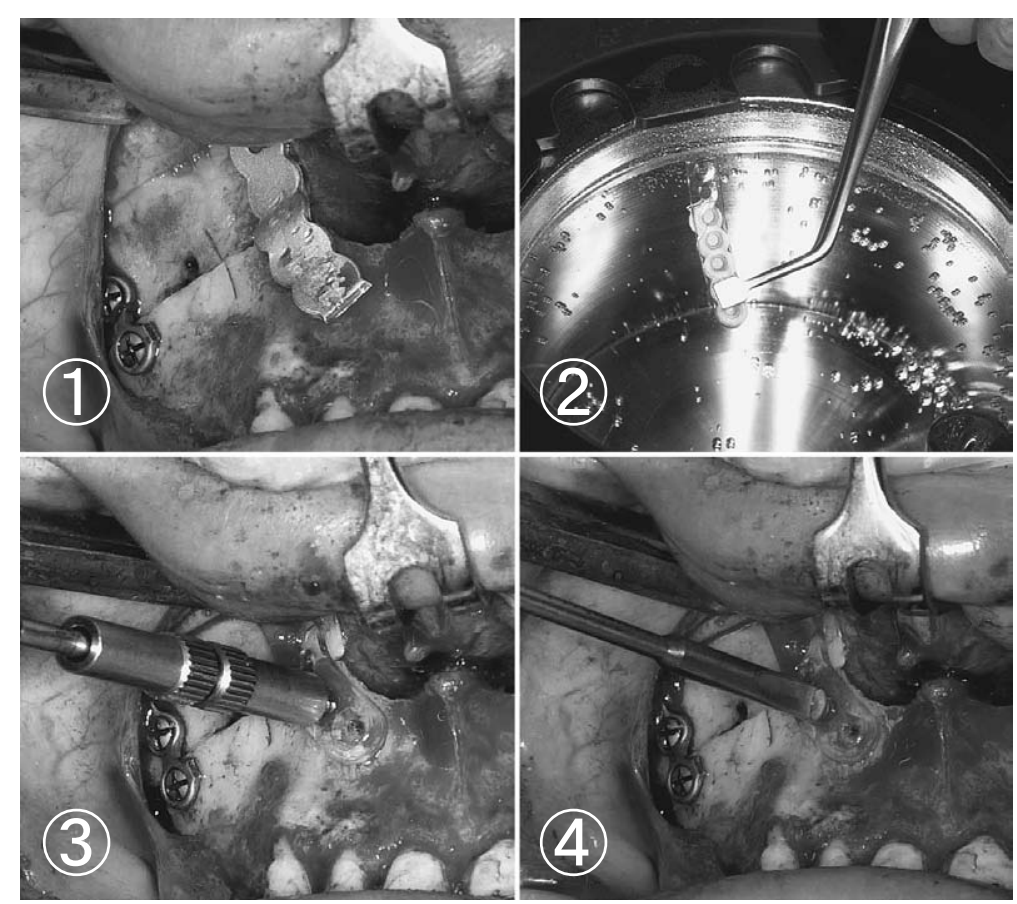

Fig. 1 Plate and screw fixation devices (NSK1403-DLT, Stryker, USA). (1) Metal templates were contoured to fit to the bone surface.

(2) The 1.0-mm thick resorbable plates could be easily bent to fit to the metal templates in hot water.

(3) After the plates were adjusted, screw holes were drilled with integrated twist drill. Threading was done with self-drilling metal tap.

(4) Screws with thread diameter of $1.7-\mathrm{mm}$ or $2.2-\mathrm{mm}$ were inserted with a screw driver.

Table 1 The evaluation criteria of bone adhesion

\begin{tabular}{cl}
\hline Score & \multicolumn{1}{c}{ Criteria } \\
\hline 0 & Complete bone adhesion is recognized. \\
1 & Bone adhesion is obscure, but the stability is maintained. \\
2 & Bone adhesion is obscure, and the stability is not maintained. \\
3 & Bone adhesion is not recognized. \\
$\mathrm{X}$ & Evaluation is impossible because of an unclear or untaken radiograph. \\
\hline
\end{tabular}

Table 2 The evaluation criteria of tenderness at the site of bone fixation

\begin{tabular}{ll}
\hline Score & \multicolumn{1}{c}{ Criteria } \\
\hline 0 (Nothing) & Tenderness is not recognized. \\
1 (Mild) & Slight tenderness is recognized. \\
2 (Moderate) & Obvious tenderness is recognized. \\
3 (Severe) & Intolerable tenderness is recognized. \\
\hline
\end{tabular}

\section{3）臨床検查値}

術後 6 か月間の血液学的検查（赤血球数, 白血球数, 血 小板数, ヘモグロビン), 尿検査（尿タンパク，尿糖， ウ
ロビリノーゲン), 生化学的検査（総タンパク, アルブミ ン, AST, ALT, ALP, LDH, $\gamma$-GTP, 総ビリルビン, 総コレステロール，BUN，尿酸，クレアチニン， $\mathrm{Na}, \mathrm{K}$, $\mathrm{Cl}, \mathrm{Ca}$ ，無機リン， CRP）功臨床検査值の異常を判定 した。判定基準では, 軽微な臨床検查異常值（わずかに基 準值から外れた值）を軽度異常，死亡または永続的な機能 不全に陥るおそれのある重篤な臨床検査異常值（いわゆる パニック值）を重度異常，軽微な臨床検査異常值の範囲を 超えるが，重篤な臨床検査異常值に至らないものを中等度 異常と規定した（Table 6)。

4）有害事象

「有害事象」とは, 術後 6 か月間の治験期間中に被験者 
Table 3 The evaluation criteria of the state of bone fixation

\begin{tabular}{ll}
\hline Score & \multicolumn{1}{c}{ Criteria } \\
\hline 0 (Extremely good) & Mobility of bone fragment is not recognized. \\
1 (Good) & Slight mobility of bone fragment is recognized, but the fixation is sufficiently maintained. \\
2 (Slightly defective) & Mobility of bone fragment is recognized, but the fixation is marginally maintained. \\
3 (Defective) & Obvious mobility of bone fragment is recognized, and the fixation is not maintained. \\
\hline
\end{tabular}

Table 4 The evaluation criteria of inflammatory reaction at the site of bone fixation

\begin{tabular}{ll}
\hline Score & \multicolumn{1}{c}{ Criteria } \\
\hline 0 (Nothing) & Redness and edema is not recognized. \\
1 (Mild) & Slight redness is recognized. \\
2 (Moderate) & Obvious redness is recognized. \\
3 (Severe) & Obvious redness and edema is recognized. \\
\hline
\end{tabular}

Table 5 The evaluation criteria of the devices

\begin{tabular}{cl}
\hline Score & \multicolumn{1}{c}{ Criteria } \\
\hline 0 & The devices are not exposed. \\
1 & The devices are exposed. \\
\hline
\end{tabular}

Table 6 The evaluation criteria of blood and urine examinations

\begin{tabular}{cl}
\hline Score & \multicolumn{1}{c}{ Criteria } \\
\hline 0 & The laboratory data are within the normal range. \\
1 & The laboratory data indicate mild abnormal values. \\
2 & The laboratory data indicate moderate abnormal values. \\
3 & The laboratory data indicate severe abnormal values which \\
& could lead to the patient's death or permanent dysfunction. \\
\hline
\end{tabular}

に生じるあらゆる好ましくない医学的事象と定義し，その うち本骨接合材との関連が否定できないものを「不具合」 と定義した。

\section{結 果}

すべての手術がトラブルなく行われ，創の哆開や術後感 染も認められず, 術後の咬合の安定性にも問題はなかった が, 1 例で術後に妊娠したために術後の CT 撮影を行わず, 画像評価を行うことができなかった。

骨接合部の圧痛評価では, 術後 1 か月の時点で 7 例 13 部位, 術後 3 か月の時点で 4 例 6 部位, 術後 6 か月の時点 で 2 例 3 部位に軽度圧痛を認めた（Table 7)。

固定状況の評価では, 術後 1 か月時に接合した骨に若干 の動摇が認められたものの固定は十分に維持されていた症 例が 2 例で, 術後 3 か月時以降は全例で良好な骨固定が得 られていた（Table 8)。

炎症反応の評価は，術後 1 か月の時点で 1 例（3.3\%） 4 部位に軽度の異常が認められたが, 術後 3 か月以降に異常 を認めた症例はなかった（Table 9)。また，骨接合材の露 出は認められなかった。

臨床検査值の評価では, 術前に 27 例 $(90 \%)$ において 何らかの検査項目で軽度の異常值を認めた。術後 1 か月で
Table 7 Results of tenderness at the sites of bone fixation

\begin{tabular}{c|cccc}
\hline Score & 0 & 1 & 2 & 3 \\
\hline 1 month after surgery & $49(23)$ & $13(7)$ & $0(0)$ & $0(0)$ \\
3 months after surgery & $56(26)$ & $6(4)$ & $0(0)$ & $0(0)$ \\
6 months after surgery & $59(28)$ & $3(2)$ & $0(0)$ & $0(0)$ \\
\hline \multicolumn{3}{c}{ Sites (Cases) }
\end{tabular}

Table 8 Results of the state of bone fixation

\begin{tabular}{c|cccc}
\hline Score & 0 & 1 & 2 & 3 \\
\hline 1 month after surgery & 28 & 2 & 0 & 0 \\
3 months after surgery & 30 & 0 & 0 & 0 \\
6 months after surgery & 30 & 0 & 0 & 0 \\
\hline
\end{tabular}

Table 9 Results of inflammatory reaction at the site of bone fixation

\begin{tabular}{c|cccc}
\hline Score & 0 & 1 & 2 & 3 \\
\hline 1 month after surgery & $58(29)$ & $4(1)$ & $0(0)$ & $0(0)$ \\
3 months after surgery & $62(30)$ & $0(0)$ & $0(0)$ & $0(0)$ \\
6 months after surgery & $62(30)$ & $0(0)$ & $0(0)$ & $0(0)$ \\
\hline \multicolumn{5}{c}{ Sites(Cases) }
\end{tabular}


Table 10 Results of blood and urine examinations

\begin{tabular}{l|rccc}
\hline \multicolumn{1}{c|}{ Score } & 0 & 1 & 2 & 3 \\
\hline Before surgery & 3 & 27 & 0 & 0 \\
1 month after surgery & 2 & 24 & 4 & 0 \\
3 months after surgery & 8 & 21 & 1 & 0 \\
6 months after surgery & 11 & 18 & 1 & 0 \\
\hline
\end{tabular}

Cases

Table 11 Results of bone adhesion

\begin{tabular}{c|cccc}
\hline Score & 0 & 1 & 2 & 3 \\
\hline 6 months after surgery & $27(13)$ & $33(16)$ & $0(0)$ & $0(0)$ \\
\hline \multicolumn{4}{c}{ Sites (Cases) }
\end{tabular}

は術前に基準值のみを示した 1 例で 1 項目に軽度異常值を 認め, 術前に軽度異常を示した 4 例でそれぞれ 1 項目 ( Hb，尿糖，LDH， $\gamma$-GTP) に中等度異常值を認めた。 しかし, 術後 6 か月において何らかの検査項目で軽度から 中等度の異常值を認めた症例は 19 例（63\%）に減少して おり，術後経過において本骨接合材に起因したと思われる 血液・尿検查值の異常やアレルギー反応を認めた症例はな かった（Table 10）。

術後 6 か月時に撮影した CT 画像所見による骨癒合の評 価では 29 例中 16 例（チタン骨接合材併用症例 12 例, 吸 収性骨接合材の久使用症例 4 例), 60 部位中 33 部位（梨 状口側縁 29 部位，頓骨下稜下 4 部位）で部分的に骨癒合 が不完全であったが，骨接合部の異常治癒過程や吸収像は 認められず，骨片間の大部分において骨癒合が認められた (Table 11)。

\section{考察}

吸収性高分子材料は，生体内で一定期間経過すると低分 子化合物に分解され，吸収される性質を持つ ${ }^{4,5)}$ 。このよ うな材料にはいくつかの種類があるが, グリコール酸や乳 酸の重合体である脂肪酸ポリエステルは安全性に優れ，製 造と物性も制御しやすいことから医療用材料として多用 途に用いられている6)。ポリ乳酸（PLA）とは生体内に存 在する乳酸の重合体であるが，天然には存在せず，グル コースと乳酸菌で発酵させて生成した乳酸を化学的に脱水 重縮合反応させることによって作られる。また，その構造 には2種類の光学異性体L体 (PLLA) およびD体 (PDLA) がある。ポリグリコール酸（PGA）も同様にグリコール 酸を脱水重縮合反応させることによって作られる。PLA や PGA は生体内で加水分解され乳酸またはグリコール酸 になり，その後吸収されて水と二酸化炭素に代謝され体外 へ排出される6)。

今回使用した生体吸収性のプレートとスクリューは，製
造元である米国 Stryker 社で開発された吸収性骨接合材で あり, その原材料は PLA と PGA の共重合体で, PLLA/ PDLA/PGA の分子比は 85/5/10 である。Stryker 社の資 料によると, 引っ張り強度および曲げ強度はそれぞれ 80 〜 90Mpa，140Mpa であり，ヒ卜皮質骨の $80 \sim 120 \mathrm{Mpa}$, $100 \sim 200 \mathrm{Mpa}$ と同程度であった。また，in vitro 分解試 験に扮いて曲げ強度は 3 か月後で $120 \mathrm{Mpa}, 6$ か月後で 110Mpa を示し, 十分な強度が骨瘾合に必要な期間維持さ れ, 分解吸収については生体内において 1 年半から 2 年で 分解吸収されるよう設計されている ${ }^{11)}$

今回の治験症例においては, 創の哆開や術後感染も認め られず，骨の治癒も全例で良好で，本骨接合材に起因した 血液・尿検査值の異常やアレルギー反応も認められなかっ たが, 術後 6 か月の時点で 2 例 3 部位の骨接合部に軽度圧 痛を認め, その後の調查でも 1 例で術後 1 年の時点でも軽 度圧痛を認めた。PGA や PLLA 製の骨接合材使用症例に おいて非感染性の組織反応による無腐性腫脹を認めたとの 報告 ${ }^{12)}$ もることから, 同様の機序による症状であった 可能性もあるが, 本症例では腫脹や発赤を認めず, 術後 1 年 4 か月経過時に撮影したCT 画像においても骨接合は良 好で明らかな炎症像を確認できなかった。

本骨接合材は厚さ $1.0 \mathrm{~mm}$ のプレートと直径 $1.7 \mathrm{~mm} も し$ くは $2.2 \mathrm{~mm}$ のスクリューからなり，本邦において用いら れている PLLA 骨接合材グランドフィックス（プレート 厚 $1.0 \mathrm{~mm}$ と $1.5 \mathrm{~mm}$ ，スクリュー径 $2.2 \mathrm{~mm}$ ，グンゼ株式会 社）やフィクソーブ MX（プレート厚 $1.5 \mathrm{~mm}$ スクリュー 径 $2.0 \mathrm{~mm}$, タキロン株式会社), PLLA に非焼成ハイドロ キシアパタイトを配合した骨接合材スーパーフィクソーブ MX（プレート厚 $1.0 \mathrm{~mm}$ スクリュー径 $2.0 \mathrm{~mm}$, タキロン 株式会社), PLLA と PGA の共重合体からなるラクトソー ブ（プレート厚 $0.9 \mathrm{~mm}$ ，スクリュー径 $1.5 \mathrm{~mm}$ と $2.0 \mathrm{~mm}$, 株式会社メディカルユーアンドエー）と比較してプレート の厚みやスクリュー径の構成はほぼ同等である。また, 加 温した蒸留水の中でプレートを軟化させて金属テンプレー トに沿った形態に曲げることが可能であることから骨面へ の適合性がよく術後の違和感が少ないうえに, 上顎骨の骨 接合に十分な強度を有していることから, 顎顔面領域の骨 接合材として有用であると思われた。ただし，本骨接合材 は比較的術後の荷重の少ない上顎骨や頭蓋骨の骨接合を想 定しており, 術後荷重の大きな下顎骨の骨接合は適応では ないので留意する必要がある。

\section{結＼cjkstart語}

ポリ-L-乳酸／ポリ-D-乳酸／ポリグリコール酸の共重合 体からなる新しい生体吸収性骨接合材の第正相試験を行い 検討したところ, 上顎骨骨接合における臨床的有用性と安 全性が確認された。 


\section{文献}

1) Jorgensen, D.S., et al.: Detection of titanium in human tissues after craniofacial surgery, Plast Reconstr Surg, 99 : 976-979, 1989.

2) Weingert, W., et al.: Titanium deposition in regional lymph nodes after insertion of titanium screw implants in maxillofacial region, Int J Oral Maxillofac Surg, 23 : 450-452, 1994.

3) Katou, F., et al.: Immuno-inflammatory responses in the tissue adjacent to titanium miniplates used in the treatment of mandibular fractures, J Craniomaxillofac Surg, 24 : 155-162, 1996.

4) Bos, R.R.M., et al.: Resorbable poly (L-lactide) plates and screws for the fixation of zigomatic fractures, $J$ Oral Maxillofac Surg, 45 : 751-753, 1987.

5) Hears, P.E., et al.: Biodegradable self-reinforced polyL/DL-lactide plates and screws in bimaxillary orthognathic surgery: short term skeletal stability and material related failures, J Craniomaxillofac Surg, $26: 363-372,1998$.

6）別所和久, 他：口腔外科領域における生体吸収性ポリ-
L-乳酸骨接合ミニプレートの開発と臨床応用, 日口外 誌, 40 : 1154-1159, 1994.

7) Harada, K., et al.: Stability after surgical correction of mandibular prognathism using the sagittal split ramus osteotomy and fixation with poly-L-lactic acid (PLLA) screws, J Oral Maxillofac Surg, 55 : 464-468, 1997.

8）岩切博宣, 他：下顎枝矢状分割法に使用した生体内吸 収性ポリ-L-乳酸骨接合スクリュー（フィクソーブ$\left.\mathrm{MX}^{\circledR}\right)$ の臨床的検討, 口科誌, $50: 43-46,2001$.

9）井上里香，他：PLLA 製スクリューを用いた下顎枝矢 状分割術後の近 - 遠位骨片の安定性, 日顎変形誌, $11: 29-34,2001$.

10）親里典子, 他：吸収性骨接合プレートを用いた下顎枝 矢状分割術後の下顎位の安定性と吸収性骨接合プレー 卜の物性解析, 日顎変形誌, $13: 21-26,2003$.

11) Ricalde, P., et al.: Degradation rate of Delta (resorbable) internal fixation: report of 2 cases, J Oral Maxillofac Surg, 62 : 250-255, 2004.

12) Bergsma, E.J., et al.: Foreign body reaction to resorbable poly (L-lactide) bone plates and screws used for the fixation of unstable zygomatic fractures, J Oral Maxillofac Surg, 51 : 666-670, 1993. 